\title{
Dual Specificity Protein Phosphatase 5
}

National Cancer Institute

\section{Source}

National Cancer Institute. Dual Specificity Protein Phosphatase 5. NCI Thesaurus. Code C111864.

Dual specificity protein phosphatase 5 ( $384 \mathrm{aa}, \sim 42 \mathrm{kDa}$ ) is encoded by the human DUSP5 gene. This protein is involved in the dephosphorylation of MAP kinase family proteins. 